\title{
The Associated Microflora to the Larvae of Human Bot Fly Dermatobia hominis L. Jr. (Diptera: Cuterebridae) and its Furuncular Lesions in Cattle
}

\author{
E Sancho, M Caballero*, I Ruíz-Martínez**/+
}

\begin{abstract}
Departamento de Parasitología, Escuela de Medicina Veterinaria, Universidad Nacional, 3000-Heredia, Costa Rica, America Central *Laboratorio de Bacteriología, Piet-UNA, Escuela de Medicina Veterinaria, Universidad Nacional, Apartado 304-3000-Heredia, Costa Rica, América Central **Departamento de Biología Animal y Ecología, Area de Parasitología, Facultad de Ciencias Experimentales, Apartado 62, Universidad de Jaén, E-23071-Jaén, España
\end{abstract}

The microflora associated to furuncular lesions, larvae and pupae of Dermatobia hominis, as well as the relationships between parasite, host and microflora associated, as a comprehensive microsystem, has been studied. One hundred and two furuncular myiasis due to D. hominis larvae in several breeds of cattle were studied and the following bacterial species were significant: Staphylococcus aureus, S. epidermidis, S. warneri, Bacillus subtilis and Escherichia coli. Closely related, the microflora associated to 141 samples from first, second, third instar larva and both external surface and larval cavities has been studied. The representative associated microflora to the larvae were: S. aureus, B. subtilis, S. hycus and Moraxella phenylpiruvica, Moerella wisconsiensis, Proteus mirabilis and P. vulgaris, M. phenylpiruvica, M. wisconsiensis, $\mathrm{P}$. mirabilis and $\mathrm{P}$. rettgeri were the representative microflora associated to 64 pupae of $\mathrm{D}$. hominis.

Key words: Dermatobia hominis - associated bacterial microflora - larvae - pupae - furuncular myiasis

Dermatobia hominis L. Jr. is a Neotropical fly responsible for most prevalent myiasis in Central and South America (from Mexico to Argentina) (Guimarães et al. 1983). Myiasis due to D. hominis or dermatobiasis (Kasai et al. 1988) is easily identified by its characteristic furuncular cutaneous lesions, characterized by a tumoration which involves both epidermis and dermis. The larva is situated in a cavity screened by a non-keratin flat epithelium that has a communication orifice with the exterior (Neel et al. 1955). This orifice is produced when the larva penetrates the host and is maintained during the entire parasitic phase, about 35 to 47 days (Sancho \& Boschini 1985).

Their effects on the wild fauna are unknown, however the bot fly maggots are a seriuos pest to livestock, specially on cattle and humans (Steelman 1976). Though the literature on its epidemiology is extensive (Guimarães \& Papavero 1966), little information about the $D$. hominis biology is available (Neiva \& Gomes 1917, Catts 1982, Sancho 1988).

This project was funded by Universidad Nacional and CONICIT of Costa Rica (Central America). Postdoctoral grant from Ministerio de Educación y Ciencia/Fulbright Comission of Spain.

${ }^{+}$Corresponding author. Fax: +34-53-212141. Email: iruiz@piturda.uja.es

Received 5 June 1995

Accepted 7 February 1996
The importance of the studies on the associated microflora to myiasis-producing flies has been showed in Australian sheep blowfly Lucilia cuprina Wied (Diptera: Calliphoridae) (Guerrini et al. 1988), the new world screwworm Cochliomyia hominivorax Coquerel (Diptera: Calliphoridae) (Bromel et al. 1983) and in the palearctic screwworm Wohlfahrtia magnifica Schin (Diptera: Sarcophagidae) (Ruíz-Martínez \& VillaReal 1995). The role of associated microflora in the attraction, oviposition, larval culture and in the new tendences of trapping flies are being intensely studied.

Adult bot fly $D$. hominis does not frequently visit the hosts (Catts 1982) but, instead, they oviposit on a carrier, usually a zoophilic fly or mosquito (Neiva \& Gomes 1917, Sancho 1988). The carrier behaviour allows the larvae to reach the host's skin. In another paper, we consider the possible attractive factor for several primarily and secondarily myiasis (Ruíz-Martínez \& Villa-Real 1995). However, the possible role and implications of bacteria associated to dermatobiasis for in vitro culture of parasitic stage -larvae- (Zeledón \& Silva 1987) is clear and it is obviously important in the knowledge of the pathogenicity or pathomorphology of the furuncular lesions (Sancho 1988).

On the associated bacterial microflora of $D$. hominis short reports are available (Sancho et al. 1986, Coronado 1989), but they are not extensive 
and do not stablish correlations between furuncular lesion and larvae or pupae. Theoretically, the exposure of the wound to field environment and, mainly, bacterial contamination resulting from numerous flies feeding on lesions, could explain some associated bacterial microflora to larvae and foruncular myiasis, but not all of them. There are some interactions larvae-microflora, host bodymicroflora and furuncle microflora-exogenous microflora that must be intensely studied.

The main objective of this study is to isolate, identify and analyze the bacterial microflora in the furuncular lesion, larvae (first, second and third instars) and pupae of $D$. hominis, and to discuss the role of these bacteria.

\section{MATERIALS AND METHODS}

The study has been carried out between April and October 1993. Hides from slaughterhouse containing active furuncular myiasis due to first, second and third instar larvae of D. hominis were recovered as follows: the exterior surface of the wound was shaved with alcohol-solution and a hot spatula was used to eliminate any remaining bacterial contamination from surrounding hide. With sterile forceps pressure was applied to the base of each tumoration for extracting the larvae and removed from the cavity with a cotton-swab in triplicate and were introduced in vials Portagerm (41996 BioMerieux) with resazurine as ox-red indicator (Barry et al. 1972, Yrios et al. 1975).

Larvae were placed in sterile vials and classified in instars according with Jobsen and Mourier (1976). All samples were kept in thermic plastic bags at $26-28^{\circ} \mathrm{C}, 80 \% \mathrm{RH}$ at darkness for analysis, within 24 to $48 \mathrm{hr}$, being the samples refrigerated at $4^{\circ} \mathrm{C}$.

From six 1st instar larva, 43 2nd instar larva and 92 3rd instar larva for associated bacterial microflora were studied. For to obtain pupae, the mature 3rd instars larva were cultured to pupae stage on a sterile filter paper in a climatic chamber at $25 \pm 1^{\circ} \mathrm{C}, 60-65 \%$ of $\mathrm{RH}$ and photoperiode $12: 12$ $\mathrm{hr}$. The pupae $(\mathrm{n}=64)$ were analyzed 20 days after (yellow pharate adult; according to Sivasubramanian \& Biagi 1983). Larvae and pupae were washed with $5 \mathrm{ml}$ of sterile saline solution and shaked in Mixo-Tub during $5 \mathrm{~min}$. The resulting fluid was analyzed for external microflora. Then, the samples were homogenized in a Potter (glass homogenizer) and a centrifugation was made. With the supernatant as a sample for internal microflora, $0.2 \mathrm{ml}$ aliquots of each dilution were made and spread in triplicate on identification media for statystical analysis.

Samples were processed following the technics recorded in Sonnenwirth (1987). The plates were incubated at $30^{\circ} \mathrm{C}$ from $48 \mathrm{hr}$ to 5 days, with or without $\mathrm{CO}_{2}$ and extend to $7 \mathrm{~d}$ for anaerobic bacteria. Gram-negative proofs were made following the system Pasco/mic/ID (Difco Lab., Detroit) with 30 substrates and 19 antibiotics. For Gram-positive and anaerobic bacteria the criteria of Krieg and Holt (1987) was followed, using 10 substrates and antibiotics of Oxoid (Ltd., London), BioMerieux (BM Lab, Paris) and Difco. The results were analyzed by API $20 \mathrm{E}$, Octals number of Difco and Micro-Scann computerized systems. The criteria employed in bacterial taxonomy followed the classification of Bergey's Manual of Systematic Bacteriology (Krieg \& Holt 1987). The percentages shown in the Tables were referred to mean bacterial counts that were found in each wound $\left(3 \times 10^{6}\right)$ and $100 \%$ is the maximum colony forming units (CFU). All data were recorded on DB3 files and proccessed by Microstad Prog. and BMDP statistical-packet.

\section{RESULTS AND DISCUSSION}

Of 102 furuncular lesions studied, on 97 bacteria were isolated $(95.1 \%$ of positive results, on five furuncular lesions none bacterial species were isolated). Ten bacterial species were identified and in decreasing order of importance (\% from total) were: S. aureus $(41.00 \%)$, E. coli $(10.33 \%)$, S. warneri (9.00\%), E. aerogens $(8.66 \%)$, S. epidermidis (8.50\%), B. subtilis $(6.00 \%)$, C. freundii $(2.50 \%)$, S. liquefaciens $(1.50 \%)$, E. cloacae $(1.00 \%)$ and $E$. agglomerans $(1.00 \%)$ (Table I).

$S$. aureus is common in piogenic proccesses but also on animal skins, as well as $S$. warneri, $S$. epidermidis and E. coli (Jansen \& Hayes 1987). The other bacteria species with enteric characteristics, probably appeared by contamination due to flies visiting-wounds, as we can usually see on furuncular lesions of Dermatobia, looking for nutritive sources (such as Stomoxys calcitrans, Musca domestica, Muscina stabulans, personal observations). It may explain the lower isolation percentages for these species obtained in our study.

Whereas only in $66.7 \%$ samples of L-I bacteria were recorded (4 bacteria species) (Table II), in the $79 \%$ samples of L-II ( 8 bacteria species) and $97.8 \%$ of L-III (19 bacteria species) samples positive isolations were recorded. The associated microflora to larvae (L-I to L-III) in the external surface were: S. aureus, S. epidermidis, B. subtilis (all of these corresponding with frequent microflora isolated in the furuncular myiasis), $S$. hycus, $S$. sciuri and M. phenylpiruvica. On the other hand, the main associated bacteria microflora to larvae in the internal cavities were: $M$. phenylpiruvica, M. wisconsiensis, P. mirabilis, P.vulgaris and B. subtilis (Table II). 
TABLE I

Microflora associated to furuncular lesions due to Dermatobia hominis in cattle

\begin{tabular}{lcccc}
\hline $\begin{array}{l}\text { Bacterial } \\
\text { species }\end{array}$ & $\begin{array}{c}\text { Presence / } \\
\text { sample }\end{array}$ & $\begin{array}{c}\% / \\
\text { total }\end{array}$ & $\begin{array}{c}\text { Mean \% } \\
\text { of isolation }\end{array}$ & $\begin{array}{c}\text { Relative importance } \\
\text { index }\end{array}$ \\
\hline Staphylococcus aureus & 85 & 83.33 & 41.00 & 34.16 \\
Staphylococcus epidermidis & 43 & 42.16 & 8.50 & 3.58 \\
Staphylococcus warneri & 32 & 31.37 & 9.00 & 2.82 \\
Bacillus subtilis & 50 & 49.02 & 6.00 & 2.94 \\
Escherichia coli & 60 & 58.82 & 10.33 & 6.08 \\
Enterobacter agglomerans & 5 & 4.90 & 1.00 & 0.05 \\
Enterobacter aerogens & 17 & 16.67 & 8.66 & 1.44 \\
Enterobacter cloacae & 10 & 9.80 & 1.00 & 0.10 \\
Citrobacter freundii & 9 & 8.82 & 2.50 & 0.22 \\
Serratia liquefaciens & 6 & 5.88 & 1.50 & 0.09 \\
\hline
\end{tabular}

\# isolated species $=10$

Bacterial absence 5

4.90

The 'relative importance index' is defined as the result of the mean percentage of isolation $\mathrm{x}$ the presence by sample and / by the total observations (in this case 102 furuncular lesions).

\section{TABLE II}

Discriminative analysis of microflora associated to furuncular lesions, larvae and pupae of Dermatobia hominis

\begin{tabular}{|c|c|c|c|c|c|c|c|c|}
\hline \multirow{2}{*}{$\begin{array}{l}\text { Type of sample } \\
\text { Bact. species/ }\end{array}$} & \multirow{2}{*}{$\begin{array}{l}\text { Furuncular } \\
\text { lesions }\end{array}$} & \multicolumn{2}{|c|}{ Larvae - I } & \multicolumn{2}{|c|}{ Larvae - II } & \multicolumn{2}{|c|}{ Larvae - III } & \multirow[t]{2}{*}{ Pupa } \\
\hline & & Ext. & Int. & Ext. & Int. & Ext. & Int. & \\
\hline Staphylococcus aureus & 34.16 & 6.00 & 1.25 & 14.88 & 0.84 & 30.44 & 0.72 & - \\
\hline Staphylococcus epidermidis & 3.58 & - & - & - & - & 2.17 & 0.04 & - \\
\hline Staphylococcus hycus & - & - & 3.39 & 5.21 & - & 1.60 & 0.44 & - \\
\hline Staphylococcus hominis & - & - & - & - & - & 0.16 & - & - \\
\hline Streptococcus haemolyticus & - & - & - & - & - & 0.26 & - & - \\
\hline Streptococcus sciuri & - & - & - & - & - & 2.20 & - & 0.11 \\
\hline Streptococcus similaris & - & - & - & - & - & - & 0.08 & - \\
\hline Streptococcus warneri & 2.82 & - & - & - & 1.77 & - & - & - \\
\hline Streptococcus xylosus & - & - & 1.10 & - & - & - & - & - \\
\hline Bacillus subtilis & 2.94 & - & - & 3.06 & 3.72 & 4.96 & 1.56 & 0.51 \\
\hline Escherichia coli & 6.08 & - & - & - & 0.51 & 0.69 & 0.11 & - \\
\hline Aeromonas salmonicida & - & - & - & - & - & - & 0.18 & - \\
\hline Proteus mirabilis & - & - & - & - & 8.62 & - & 4.45 & 4.22 \\
\hline Proteus vulgaris & - & - & - & - & - & - & 4.21 & - \\
\hline Proteus rettgeri & - & - & - & - & - & - & 0.90 & 2.25 \\
\hline Providencia stuartii & - & - & - & - & - & - & 0.11 & - \\
\hline Enterobacter aerogens & 1.44 & - & - & - & - & - & - & - \\
\hline Enterobacter agglomerans & 0.05 & - & - & - & - & - & - & - \\
\hline Enterobacter cloacae & 0.10 & - & - & - & - & - & - & - \\
\hline Moerella wisconsiensis & - & - & - & - & 13.92 & - & 4.79 & 9.38 \\
\hline Moraxella phenylpyruvica & - & - & 11.80 & 0.66 & 10.05 & - & 9.54 & 10.00 \\
\hline Citrobacter freundii & 0.22 & - & - & - & - & 0.08 & - & - \\
\hline Serratia sp. & - & - & - & - & - & - & - & 0.07 \\
\hline Serratia liquefaciens & 0.09 & - & - & - & - & - & 0.07 & - \\
\hline Serratia marscescens & - & - & - & - & - & 0.08 & - & - \\
\hline Total $=25$ & 10 & 1 & 4 & 4 & 7 & 10 & 14 & 7 \\
\hline
\end{tabular}

(\#): positive isolation reffering to relative importance index in each sample-kit; (-): negative isolation 
Only bacteria species belonging to wounds were isolated on the external surface of larvae, increasing the number and relative importance rate of isolation from second to third instar larvae (from only one bacteria species isolated -S. aureus- in L$\mathrm{I}$, to four bacteria isolated in L-II and ten bacteria species isolated in L-III) (Table II). When we tried to measure the statistical similitude within samples from wounds and from external surface of larvae by Sorensen's coeficient, the percentages obtained were $85.0 \%$ (for L-II) and $96.0 \%$ (For L-III) respectively. These facts show that the microflora associated with larval surface was only a draging product from wounds.

On the contrary, the results obtained from internal body (digestive and respiratory tracts) of larvae indicates that these bacteria were not significant and $S$. aureus was never isolated in significant levels from the internal body of the larvae, whereas other bacteria such as $M$. phenylpiruvica, $M$. winconsiensis, $P$. mirabilis, $P$. vulgaris and B. subtilis are the dominant ones (Table II) and were never isolated significantly from wounds. It is very probable that these bacteria species stablish a competence against those from wounds (Greemberg et al.1970) and they may constitute endosymbionts of the larvae of $D$. hominis, that contain a bactericide or bacteriostatic substance against foreign microflora (Baba et al. 1987). Our results seem to point out in this direction: the larvae contains their proper bacteria microflora (this phenomenon is clear in L-II and L-III) and these bacteria reject the foreign one ingested by the larval nutrition.

Probably, this phenomenon will be common in myiasis-producing flies: similar results have been obtained on Australian sheep blowfly Lucilia cuprina (Emmens \& Murray 1982), in new world screwworm Cochliomyia hominivorax (De Vaney et al. 1973) and in palearctic screwworm fly Wohlfahrtia magnifica (Ruíz-Martínez \& VillaReal 1995).

As a whole, the number of bacteria species isolated increased from instar I to instar III (from 4 to 19) (Table II) and decreased from instar III to pupae (from 19 to 7) (Table II). Obviously, the increasing size of the furuncular hole (due to larval growth) and its exposed surface to the environment produces a correlative increase of microflora associated or imported (from environment). Moreover, the infestation itself increased the microflora coming from feeding fly visiting-wounds. In this way, the high number of flies feeding on wound exudates may be the major cause of foreing contamination of the furuncles under natural conditions (Hawley et al. 1951). The larger development time of third instar larvae (Sancho \& Boschini
1985) could favour the continuous contamination throughout the field environment and wound-visiting flies.

On the other hand, although one bacteria capable of producing piodermitis as $S$. aureus was isolated from the wound-samples, no secondary bacterial infection was recorded. Noticeably there have been no cases of acute secondary bacterial infection in human skin parasitized by warble flies (Brenes \& Maezerville 1963). Nevertheless, when the parasite attacks other host tissues a secondary bacterial infection is recorded (such as a meningoencephalitis, case reported by Céspedes et al. 1962). These may suggests that the skin has an immunological function with an inhibitory effect on bacteria present in the wound (Patterson \& Edelson 1982). Another possibility is the larval substance with bactericide properties in D. hominis (as suggested the data of Picado 1935) and in other warble flies (Bennett 1955, Beesley 1968) as Baba et al. (1987) showed with the antibacterial effect of 'sarcotoxins I, II and III' from flesh flies. In this way, Coronado (1989) observed the bactericide effect of larval extracts from $D$. hominis against $S$. aureus, S. epidermidis, S. caprae and Streptococcus spp. Independently or together, showed the absence of acute secondary bacteria infection on human skin and bovine cattle hides as facts for intensive studies in the future, but with one noteworthy difference: the hypothesis on antibacterial properties of $D$. hominis's larval extracts working on living tissues (not in carcases, decayed or dead tissues as flesh-flies and 'sarcotoxins').

A group of 64 pupae of $D$. hominis was studied (Table II) and in $44.75 \%$ positive results were obtained. This relative sterility was observed by Greemberg et al. (1970) for pupae of several flies. Seven bacteria species were isolated and only four with relative importance: $M$. winconsiensis, $M$. phenylpiruvica, P. mirabilis and $P$. rettgeri. These bacteria species were isolated from internal body of first, second and third instar larvae (Table II) and never isolated in the furuncular myiasis.

Observing the bacteria microflora associated to different studied samples (Table II), we conclude that $M$. phenylpiruvica, $M$. wisconsensis and $P$. mirabilis, plus $B$. subtilis constitute the microflora proper of larvae and pupae of Dermatobia, and secondarily $P$. vulgaris and $P$. rettgeri. Curiously, these bacterial species are commonly found in other myiasis producing-flies (Emmens \& Murray 1982, Bromel et al. 1983, Ruíz-Martínez \& Villa-Real 1995) with different life-habits. This is the first record about the presence of $M$. wisconsensis (Hickman et al. 1984) in animal tissues.

As stated above, we assumed that the antibacterial properties of some bacteria species (Baba et 
al. 1987, Coronado 1989), alone or added to the skin immunological factors (Patterson \& Endelson 1982) for explain the results of Tables I and II. Nevertheless, another idea suggests the role of specific bacteria associated to the larvae of $D$. hominis (Table II). Recently Guerrini et al. (1988) showed that some bacteria create a double effect. First, to produce smells attractive to gravid females (perhaps for the carriers?), that explain the prevalence of furuncular myiasis (Thomas, 1988). Moreover, faty acids coming from wounded tissues and other decomposed tissues would justify the attraction for this wounds (Mulla et al. 1977). Second, to maintain a $\mathrm{pH}$ coinciding with the maximum rates of larval survival. Certainly, the $\mathrm{pH}$ rates observed over 419 foruncular lesions due to $D$. hominis were very constant $(6.88 \pm 0.05)$ and its variations for samples of second and third instars larvae and $\mathrm{pH}$ from the outer or inner part of the cattle hides were very small (personal observations) and coincides with the optimal pH for S. aureus (Tables I, II).

In our opinion the furuncular lesion, the larvae and its associated microflora must be considered as a whole micro-habitat. It is possible that the external microflora would be essential for maintaining the $\mathrm{pH}$. The optimal $\mathrm{pH}$ and bacteria would be neccesary for an adequate larval development. The wound and larvae metabolism would be probably adequate for attractions of new carriers (with egg mass adhered). The larvae associated microflora would help this process and provide an adequate inner-habitat to larvae. The understanding of this complex situation may lead to succes for in vitro culture of larval instars, to better undestand of the larval development, the development of traps and to comprehensive studies about biology of $D$. hominis.

\section{ACKNOWLEDGMENTS}

To Mr Gustavo Chinchilla and Dr Frédéric A Poudevigne (USDA-ARS-Screwworm Program), Dr M Miranda and Dr B Badilla (Montecillos Slaughterhouse), Dr C Boschini and Dr L Torres (National University of Costa Rica) for sampling and research facilities. To Dr R Villa-Real and Dr L Extremera for manuscript corrections and methodological designs from Bacteriological Research Unit of Jaén University. To Spanish Airlines Iberia for care, transport assistance and effectiveness. To $\mathrm{Mr}$ JJ Richmond, Mr JB Granados and Mr F Corrales (USDAARS-Screwworm Program) for technical assistance in field trials and Mr J González Soto, Ms G Hernndez Gómez and Ms L Lang from Bacteriological Department of Universidad Nacional, Costa Rica. To Ms G Bolaños from U.S. Embassy of San José (Costa Rica) for english corrections. To United States Department of Agriculture (USDA), Agricultural Research Services (ARS), Screwworm Program for Research facilities, specially to Research-Leaders Dr FD Parker and Dr JB Welch and the Administrative-Program Mr R Aguirre.

\section{REFERENCES}

Baba K, Okada M, Kawano T, Komano H, Natori S 1987. Purification of Sarcotoxin III, a new antibacterial protein of Sarcophaga peregrina. J Biochem 102: 69-74.

Barry AL, Fay GD, Sauer RL 1972. Efficiency of transport medium for the recovery of aerobic and anaerobic bacteria from applicator swabs. Appl Microbiol 24: 31-33.

Beesley WN 1968. Observations on the biology of the warble-fly (Hypoderma, Diptera, Oestridae). II. Bacteriostatic properties of larval extracts. Ann Trop Med Parasitol 62: 8-12.

Bennett GF 1955. Studies on Cuterebra emasculator (Diptera: Cuterebridae) and a discussion of the status of the genus Cephenemyia. Can J Zool 33: 7598.

Brenes F, Maezerville A 1963. Daños en pieles. Rev Univ Costa Rica 40: 72-78.

Bromel M, Duh FM, Erdmann GR, Hammack L, Gassner $\mathrm{G} 1983$. Bacteria associated with the screwworm fly Cochliomyia hominivorax (Coquerel) and their metabolites, p.791-800. Endocytobiology, Vol.II. Walter de Gryter \& Co., Berlin.

Catts EP 1982. Biology of New World bot flies: Cuterebridae. Ann Rev Entomol 27: 313-338.

Céspedes FR, Arguedas J, Guillén G, Hevia G 1962. Dermatobiasis mortal. Acta Med Costarricense 5: 175-181.

Coronado A 1989. Aspectos imunológicos, atividade antibacteriana e efeito de várias doses de ivermectina sobre larvas de Dermatobia hominis (Linnaeus Jr., 1781) (Diptera: Cuterebridae). M.Sc. Thesis, Univ. Fed. Rio Janeiro (Brasil).

De Vaney JA, Eddy GW, Ellis EM, Harrington R 1973. Attractancy of inoculated and incubated bovine blood fractions to screwworm flies (Diptera: Calliphoridae): role of bacteria. J Med Entomol 10: 591-595.

Emmens RL, Murray MD 1982. The role of bacterial odours in oviposition by Lucilia cuprina (Wiedemann) (Diptera: Calliphoridae), the Australian sheep blowfly. Bull Ent Res 72: 367-375.

Greemberg B, Kowalsky JA, Klowden M 1970. Factors affecting the transmission of Salmonella by flies: natural resistance to colonization and bacterial interference. Inf Imm 2: 800-809.

Guerrini VH, Murphy GM, Broadmeadow M 1988. The role $\mathrm{pf} \mathrm{pH}$ in the infestation of sheep by Lucilia cuprina larvae. Int J Parasitol 18: 407-409.

Guimarães JH, Papavero N 1966. A tentative annotated bibliography of Dermatobia hominis (Linnaeus Jr., 1781) (Diptera: Cuterebridae). Arq Zool (São Paulo) 14: 219-294.

Guimarães JH, Papavero N, Do Prado AP 1983. As miíases na região neotropical (identificação, biologia, bibliografia). Rev Bras Zool 1: 239-416.

Hawley JE, Penner LR, Wedberg SE, Kulp WL 1951. The role of the house fly Musca domestica in the multiplication of certain enteric bacteria. Am J Trop Med 31: 572.

Hickman FW, Huntley GP, Saitoh Y, Steigerwalt AG, 
Farmer J, Brenner DJ 1984. Moerella wisconsensis, a new Genus and Species of Enterobacteriaceae found in human stool specimens. J Clin Microbiol 19: 460-463.

Jansen BC, Hayes M 1987. The relationship between the skin and some bacterial species occurring on it in the Merino sheep. Ondersteepoort J Vet Res 54: 107-111.

Jobsen JA, Mourier H 1976. The morphology of the larval instars and pupa of Dermatobia hominis L.Jr. (Diptera: Cuterebridae). Entomol Ber 32: 218-224.

Kasai T, Cordero del Campillo M, Euzeby J, Gaafar S, Hiepe T, Himonas CA 1988. Standarized Nomenclature of Animal Parasitic Diseases (SNOAPAD). Vet Parasitol 29: 229-326.

Krieg NR, Holt JG 1987. Bergey's Manual of Systematic Bacteriology. Vol.I. The Williams \& Wilkins Co., Baltimore.

Mulla MS, Hwang YS, Axelrod H 1977. Attractans for synanthropic flies: chemical attractans for domestic flies. J Med Entomol 70: 644-648.

Neel WW, Urbina O, Viale E, De Alba J 1955. Ciclo biológico del tórsalo (Dermatobia hominis L.Jr.) en Turrialba, Costa Rica. Turrialba 5: 91-104.

Neiva A, Gomes JF 1917. Biologia da mosca do berne (Dermatobia hominis) observada em todas as suas fases. Ann Paulistas Med Cirug 8: 197-209.

Patterson AKJ, Edelson RL 1982. Interaction of T cells with epidermis. Br J Dermatol 107: 117-122.

Picado C 1935. Sur le principe bactericide des larvas des mouches. Bull Biol Fr et Belg 69: 409-438.
Ruíz-Martínez I, Villa-Real R 1995. Microflora associated to sheep myiasis caused by screwworm fly Wohlfahrtia magnifica (Schin.) (Diptera: Sarcophagidae). Appl Microbiol in press.

Sancho E 1988. Dermatobia, the Neotropical warble fly. Parasitol Today 4: 242-246.

Sancho E, Boschini C 1985. Observación del período parasitario de Dermatobia hominis en Bos taurus (Romo-Sinuano). Cienc Vet Costa Rica 2: 2-3.

Sancho E, Rodríguez F, Torres L, Bolaños J 1986. Flora bacteriana presente en la lesión producida por Dermatobia hominis en vacuno. Cienc Vet Costa Rica 8: 23.

Sivasubramanian P, Biagi M 1983. Morphology of the pupal stages of the fleshfly Sarcophaga bullata (Parker) (Diptera: Sarcophagidae). Int J Insect Morphol Embryol 12: 355-359.

Sonnenwirth AC 1987. Manual of Clinic Microbiology. American Society for Microbiology, Washington D.C.

Steelman CD 1976. Effects of external and internal arthropods parasites of domestic livestock production. Ann Rev Entomol 21: 155-178.

Yrios JW, Balish E, Helstad A, Field C, Inhorn S 1975. Survival of anaerobic and aerobic bacteria on cotton swabs in three transport systems. J Clin Microbiol 1: 196-200.

Zeledón R, Silva S 1987. Attemps to culture the parasitic stage of Dermatobia hominis (L.Jr.) in vitro (Diptera: Cuterebridae). J Parasitol 73: 907-909. 